\title{
经济途径对地缘政治格局的影响机制及其 空间表现研究进展
}

\author{
曹 原 1,2 , 葛岳静 ${ }^{1,3}$, 王淑芳 ${ }^{1}$, 胡志丁 ${ }^{3}$ \\ (1. 北京师范大学地理学与遥感科学学院, 北京 $100875 ; 2$. School of Geography, University of Wisconsin-Madison, \\ Madison 53706, USA; 3. 中国西南地缘环境与边疆发展协同创新中心, 昆明 650500)
}

\begin{abstract}
摘 要: 随着中国崛起, 世界主要大国将战略中心转移至亚洲并通过各种经济组织和经济联盟等经济途径重塑中国 周边环境, 由此导致中国周边地缘环境形势变得极其复杂。中国则通过共建“一带一路”、亚洲基础设施投资银行、 金砖国家开发银行等经济途径化解。本文按照全球一区域一国家间的尺度, 探讨了国际经济组织、经济联盟和国 家间经济相互依赖等 3 种主要经济途径对地缘政治格局的影响机制及空间表现。结果表明: 通过国家间经济依赖 的不对称性改变各国权力大小, 进而影响地缘格局中地缘体的权力分配, 其空间表现主要为影响地区冲突和改变 国家地缘空间影响范围。而国际经济组织和经济联盟则通过权力再平衡影响地缘政治格局, 其空间表现主要为数 量增长、交错分布和空间范围扩大。中国学者对如何通过经济途径增强地缘政治影响力、改善中国地缘环境的研 究不够充分。中国作为崛起中的大国, 应更为关注经济实力的增强对周边乃至世界地缘政治格局的影响。为此, 应加强以下几个方面研究: (1) 将经济相互依赖转化成为有效的地缘影响力; (2)利用国际经济组织和经济联盟拓展 中国地缘政治空间; (3) “带一路”空间走向及沿线国家; (4)多尺度经济途径影响效应分析; 5)运用定量模拟方法探 求国家地缘影响力演变的影响因素以及驱动机制等,为中国的地缘战略提供理论支撑和研究实证。
\end{abstract}

关 键 词: 经济途径; 地缘政治格局; 经济相互依赖; 国际经济组织; 经济联盟

\section{1 引言}

随着中国经济的迅速发展, 全球财富和战略资 源加速东移, 世界经济重心逐渐转向亚洲, 全球权 力格局出现新的分化和重组, 地缘政治格局由冷战 后美国主导的一超独霸逐渐向一超多强演变, 国家 与国家集团之间的地缘战略也在发生变化(陆大道 等, 2013)。随着中国的崛起, 美国加紧战略东移, 实施 “亚太再平衡”战略; 欧盟从推动贸易出发, 将 战略重点从美国转移到亚洲(Dent, 1999); 俄罗斯推
行 “亚洲新外交” (1),力图扩大在中国周边地区的影 响力; 再加上东海问题、南海问题、钓鱼岛问题及台 湾问题等, 中国周边地缘政治格局的形势极其复 杂。2013 年, 习近平主席先后提出了共建“丝绸之 路经济带”和“海上丝绸之路”的战略构想 ${ }^{2}$ 。中国 也借此机遇, 积极推动亚洲基础设施投资银行、金 砖国家开发银行、中国一东盟命运共同体等重大合 作倡议,希望通过经济手段来化解中国崛起过程中 产生的地缘问题(吕涁, 2015)。

从经济角度来讲,世界政治格局变化实际上是

收稿日期: 2015-07; 修订日期: 2015-12。

基金项目: 国家自然科学基金项目(41171097,41401157); 国家科技支撑计划项目(2012BAK12B03); 国家公派研究生项目 (201406040147) [Foundation: National Natural Science Foundation of China, No.41171097, No.41401157; National Key Technology Support Program, No.2012BAK12B03; Scholarship Program of China Scholarship Council, No.201406040147]。

作者简介: 曹原(1988-), 女, 山东临沂人, 博士研究生, 主要研究方向为全球化与地缘环境, E-mail: rarerabbit@ 163.com。 (1)http://www.people.com.cn/GB/channel2/18/20000824/200768.html。 (2)http://news.xinhuanet.com/fortune/2014-08/11/c_1112013039.html。 
国家权力和利益的再分配。在新地缘政治时期, 经 济利益成为国家地缘战略的主要参量(李正等, 2014), 各个国家把提高经济地位和增强经济实力 作为提升国际地位重要的战略目标, 通过多元化的 经济手段来确保国家独立与国家安全。在当前的 整体环境下, 经济途径已经成为了一国拓展利益空 间乃至战略空间的重要手段(毛汉英, 2014), 国家间 任何经济往来、交流与合作, 成立的各经济组织和 经济战略都具有地理上的空间导向意义, 能够化解 或改变国际间的地缘格局。传统意义上的政治盟 友会因为经济利益而产生矛盾(刘雪莲等, 2011), 同 样, 政治理念不同的两方会因共同的经济利益达成 妥协。随着国家间经贸往来和对外投资数额以及 参与国数量的增加, 各国各地区经济利益互相渗 透, 在经济上的相互依存逐渐加深, 使经济途径成 为处理外交事务的重要渠道。因此, 在此背景下研 究经济途径对地缘政治格局的影响具有重要的理 论和现实意义。

由国家之间经贸往来和对外投资等经济联系 而导致地缘政治格局发生变化的最直接的经济途 径主要包括两个方面: 一方面, 国家通过加人国际 经济组织或缔结经济联盟而改变地缘政治版图 (Walt, 1987); 另一方面,一国可以通过经济上的相 互依赖改善与其他国家的地缘关系从而扩大地缘 政治空间范围(Keohane et al, 1987)。经典地缘政治 理论均从权力和空间两个视角来论述国家通过拓 展其政治利益空间, 不断与其他国家相抗衡的过程 (胡志丁等, 2015)。近年来, 学者们还广泛地从全 球、区域及热点地区等多个尺度探讨了地缘政治格 局问题(王在邦, 2008; Evans, 2011; 林利民, 2012)。 本文将结合以上两个维度, 从权力与空间两个视角 和全球、区域、国家间三个尺度探讨上述两方面经 济途径对地缘政治格局影响机制和空间表现,并从 中国实际出发, 提出加强相关研究的建议。

\section{2 国际经济组织和经济联盟对地缘政 治格局的影响}

国际经济组织指的是国家之间在经济往来日 渐密切的基础上,利用经济条约或经济协定的约束 而建立起来的国际性经济机构。经济组织的目的 是为了协调成员国之间的经济关系并推动、促进成 员国之间的经济合作, 致力于推进经济一体化进
程。国际经济组织的涵义分为广义和狭义。广义 的国际经济组织包括国家政府间的经济组织和非 政府间的经济组织。狭义的国际经济组织仅指国 家政府间的经济组织。国际经济组织的一个重要 标志是由国家或代表国家的单位和组织组成。经 济联盟指的是参与国在建立关税同盟的基础上,制 定相同的经济政策, 使货币在流通方面更加顺畅， 最终实现同盟国之间商品和生产要素的自由流动, 形成超国家的经济协调机构。对参与国来说, 经济 联盟内国家之间的合作更加深人和密切。

\section{1 影响机制和途径}

从权力视角来看, 国际经济组织和经济联盟的 建立都会使国家之间的权力发生再平衡(McGowan et al, 1975; He, 2008), 进而对地缘政治格局产生影 响。从全球层面来看, 主权国家加人一个或多个经 济组织或经济联盟, 虽然降低了国家之间的经济交 往成本(张胜军, 2004), 但同时又受到不同经济组织 或经济联盟的汼制, 其地缘影响力势必会发生改 变, 并导致国家之间的权力格局发生变化。同时, 自身实力较弱的国家可以通过缔结经济联盟的方 式提高共同的国际地缘地位, 获得与其他实力较强 的国家以及组织或联盟对抗和平衡的资本(Papayoanou, 1997)。如东南亚国家联盟在 1992 年提出建 立自由贸易区,通过推进贸易自由化提高合作水平 和经济一体化建设, 提升了东盟的整体实力, 也使 东盟各国国际地位迅速提升, 增强了地缘影响力。

从经济组织和经济联盟内部层面来看,一方 面,各成员国通过内部经济政策的调整而形成更紧 密的经济联系(Oneal et al, 1999, 2003; Capannelli et al, 2010), 这一过程会削弱经济联盟和经济组织中 的国家之间的地理边界, 使国家之间边界变模糊 (Thomes, 2013), 联盟或组织朝着超国家经济体(super-state)的方向发展(Murphy, 2013); 另一方面, 各 成员国还通过牺牲或让渡本国的部分权利来寻求 更加长远的利益(Krause et al, 1975)。这些权利包 括国家之间建立共同市场所需让渡的权利以及别 国干涉本国经济运行的权利，国家让渡经济权利的 多寡使得某些国家拥有比其他国家更加丰富的权 力来源。在这种境况下, 占主导或优势地位的国家 拥有更多的话语权, 可以通过组织或联盟的约束力 量向其他国家施加压力。因此, 在经济组织和经济 联盟内部,弱势国家的选择倾向在很大程度上影响 了国家之间的地缘政治格局。有学者认为弱势国 
家为了增强自身的实力而选择与实力较强的一方 结盟, 以增加在处理经济事务中的话语权; 另外一 种观点则正好相反,认为该类国家会选择实力较弱 的一方结盟, 目的是为了维持组织或者联盟内部的 权力平衡(Walt, 1985)。但有一点可以肯定的是, 无 论一国选择倾向如何, 其目的都是为了增强自身实 力以及可运用的国家权力, 也势必会引起经济组织 和经济联盟内部的地缘政治结构发生改变。

\section{2 国际经济组织和经济联盟的空间发展}

\subsection{1 数量增多,空间上交错分布}

全球化使地缘政治的互动更加密切, 也进一步 削弱了地区地缘政治的独立性(金灿荣, 2008)。经 济全球化与一体化进程中, 国家之间的经济联系和 相互依赖逐渐加深, 但主权国家因受到地理边界的 限制, 所以许多国家希望通过设立国际经济组织来 克服国家行政边界的局限性, 以此来协调国家之间 的主张与政策,通过强化国家之间的经济联系与经 济合作, 促使国际经济关系能够超越国家之间的行 政边界, 共同发展经济(周启元, 1991)。因此,国际 经济组织是国家间经济联系日益密切,经济生活日 趋国际化、一体化的产物, 是国际地缘经济格局发 生变化的一个重要表现。自从 1815 年莱茵河沿岸 国家成立了世界上最早的国际经济组织一一莱茵 河委员会以来, 国际经济组织和经济联盟的数量逐 渐增加。在世界范围内也逐渐发展形成若干经济 集团、经济联盟和经济组织相互竞争的地缘格局 (Sparke M, 2007)。根据英国《经济学人》2009年公 布的数据, 截至目前世界上已建立的区域或次区域 的经济合作组织达 109 个, 其中最著名的有亚太经 济合作组织、欧洲联盟、北美自由贸易区、非洲自由 贸易区、非洲联盟、东南亚国家联盟和海湾合作委 员会等。无论是第二次世界大战刚结束时成立的 国际货币基金组织, 冷战时期的经济互助委员会, 冷战后期成立的亚太经合组织, 冷战结束后的欧洲 联盟, 还是 2015 年 1 月 1 日正式启动的欧亚经济联 盟等,这些经济组织都对世界地缘政治格局产生了 重要影响。

随着全球化的深人, 各国为了满足不同的经济 合作和空间发展需求, 在世界范围内形成了由不同 国家组成、区域范围各异的经济组织和经济联盟, 并形成了在空间上交错重叠的地缘政治格局。如 亚太经合组织(APEC), 其空间范围内涵盖的东南亚 国家联盟、东亚峰会、北美自由贸易区等组织, 同
时,与上海合作组织、金砖国家、拉美经济体系等都 有交错。在国家层面,一个国家会根据其地理位置 及战略平衡需要加人多个经济组织或经济联盟 (Ganesan, 2000), 参与更多的经济博弯。在经济组 织与经济联盟空间上交错分布的同时,各国也通过 经济组织或联盟有效地拓展本国地缘政治空间, 并 对其他地缘体的地缘政治空间进行挤压。例如中 国通过 “上海合作组织”进一步深化了与俄罗斯和 中亚国家之间的关系, 拓展了中国北部与西北部的 地缘政治空间(张根海, 2012)。通过与东南亚国家 成立中国一东盟自由贸易区拓展了中国在海上的 地缘政治空间,但印、越、老、缅、柬、泰六国在 2000 年成立的涺公河一恒河流域合作组织, 又在一定程 度上挤压了中国与东盟国家进行合作的空间。

\subsection{2 空间范围扩大}

近年来,许多区域经济合作组织通过扩大影响 力和规模, 在空间上进行扩张, 并努力推进市场、经 济和社会一体化的进程(毛汉英, 2014)。具体表现 就是越来越多的国家加人到各个国际或区域经济 组织和联盟当中, 通过经济组织或经济联盟促进本 国的经济发展和竞争力提升,增强在国际上或区域 内的话语权。如欧洲联盟自 1952 年成立以来经过 5 次扩张, 从最初的 6 个成员国发展至现在的 28 个 成员国,在空间范围扩大的同时对俄罗斯的地缘政 治空间形成了挤压; 东南亚国家联盟也从最初的 5 个国家发展至现在的 10 个国家,还在 20 世纪 90 年 代初发起了一系列以东盟为中心的区域合作机 制。同时, 区域经济组织和联盟也在向世界范围内 扩张, 从发达国家之间的“北北合作”向发达国家和 发展中国家之间的“南北合作”过渡。如 APEC 在 1989 年 11 月成立时只有 12 个成员, 现在发展到 21 个成员,还有东盟秘书处、太平洋经济合作理事会 和太平洋岛国论坛 3 个观察员。APEC的 21 个成员 体, 从空间分布来看, 遍布东亚、北美、南美和大洋 洲; 就经济发展水平来看, 既有发达国家, 又有发展 中国家。

\section{3 国家间经济相互依赖对地缘政治格 局的影响}

地缘政治格局是国家间权力关系的交织,在经 济方面，国家之间的贸易、投资等方面交流促使国 家之间产生了相互依赖,这一过程中成本一收益的 
差异决定了国家间的经济相互依赖程度的不同(罗 伯特・基欧汉等, 2002)。国家间经济相互依赖关系 程度的差异能否转化为有效的国家权力、抑制还是 促进国家间空间的冲突, 对地缘政治格局将产生重 要的影响。

\section{1 权力视角下的经济相互依赖}

国家间的经济相互依赖关系通过影响国家之 间的权力关系来改变地缘政治格局。经济相互依 赖如何转化成国家权力, 在国际关系学领域有详细 的解释。其中最著名的有现实主义和自由主义两 个学派。现实主义派学者认为: 国家之间的经济交 流和往来产生的互利互惠往往是不对等的, 不同的 国家从经济联系和往来中的获益不同, 如果切断经 济联系和往来, 各国所付出的代价有所不同, 优势 国对于这种变化的调整成本要小于劣势国(华尔 兹, 2003), 这种不对等的关系可以影响国家之间的 权力关系(Cooper, 1968)。优势国通过挖掘和利用 这种经济领域的优势, 将其运用到政治领域去影响 他国(Hirschman, 1980), 改变国家之间的权力重心， 影响区域的地缘格局。自由主义派学者 Keohane (2005)进一步从敏感性和脆弱性的角度对经济相互 依赖转化成国家权力的机制进行了分解(罗伯特基欧汉等, 2002), 其中敏感性强调一国感受外部地 缘环境变化的灵敏程度, 灵敏程度低的国家可能获 得更多的权力; 脆弱性强调外部环境发生变化后国 家调整成本的高低, 更倾向于表示国家硬实力, 也 可以在某种意义上代表着一国的权力大小 (Kenneth, 2003)。

虽然上述两派学者观点有分歧, 但前提假设是 相同和确定的, 即把一国的政治决策和行为看作是 经济和政治互动的产物, 而政治决策和行为都是理 性的, 其基本的争论点是建立在不平等的相互依赖 能否直接转化成国家权力。受到批判地缘政治学 理念的影响(Dodds, 2001; 胡志丁等, 2015), 有学者 对上述假设提出质疑, 认为不平等的经济相互依赖 不能直接转化成为国家权力,一国对他国依赖程度 较低并不能使这个国家将这种优势直接转化成改 变地缘关系的一个影响因素(Wagner, 1988)。其原 因有二: 一是在经济领域中, 相互依赖所包含的是 市场权力可以转化为效益, 并且能够提高一国在处 于风险时期的承受能力。在这种情况下, 不平等的 经济相互依赖有可能无法转化成为政治影响力; 二 是当处于弱势的一方在承受来自另一方可能由经
济相互依赖的优势转化而成的政治优势所作出改 变时,如果改变的成本大于接受优势国的经济制裁 所承受的损失,那么弱势国宁可选择经济制裁也不 会作出改变。在这种情况下,即使一国在与其他国 家的经济联系中占有优势, 但这种优势也并不足以 转化成为政治影响力而改变地缘政治格局(Wagner, 1988)。

\section{2 空间表现}

国家间的经济相互依赖对地缘政治格局在空 间上的影响主要有两种形式。一是由于国家之间 的经济相互依赖关系引发的冲突而改变地缘政治 格局; 另一种是一国通过加强与其他国家在经济上 的依赖程度来扩展其地缘政治空间。

\subsection{1 区域冲突}

20 世纪 80 年代以来, 世界范围内局部地区的 战争和冲突从未停止过,虽然冲突没有扩大至全球 量级,但仍对世界地缘政治格局产生了重要影响 (毛汉英, 2014)。按照地缘政治学的基本观点, 在国 家关系中, 为了谋求领土、资源等生存条件和生存 空间的支配权与控制权, 对抗一般是不可避免的 (孔小惠, 2010; 陆大道等, 2013)。从经济角度来看, 国与国之间在商品市场、资源供给、资金技术流向 等多个方面形成了依赖、竞争或者合作的关系,这 些关系存在着引发对抗和冲突的可能性(Barbieri, Schneider et al, 1999; 余万里, 2003; 广艳湘, 2007)。

从经济相互依赖的角度来看(Stein, 2003), 如果 切断经济上相互依赖的国家之间的经济联系,各国 都会产生一定的调整成本, 国家之间为避免产生额 外的成本而选择维持现状, 而且依赖的程度越高, 地缘政治格局也就越容易维持在和平稳定的状态 (Polachek, 1980)。当国家之间的相互依赖不对称 时,外来的“渗透”损害了弱势国家的利益, 当强国 之间因有限的市场和资源而产生竞争时, 国家之间 经济上的联系非但不会促进和平, 反而会引起更多 国家间的冲突(Barbieri, Levy, 1999)。

国家间的经济相互依赖是否通过改变国家之 间的联系而改变地缘政治格局,不能仅局限于静态 分析。基于对未来期望值进行的动态分析, Copeland(1996)认为对未来贸易的预期水平才是真正决 定国家间冲突还是和平的变量。当未来的收益大 于可能的损失时,维持地缘政治格局现状的可能性 越大; 反之, 打破现状的可能性越大, 发生冲突并促 使地缘空间格局再分配的可能性越大。此外, 经济 
相互依赖能否引发冲突还取决于地缘体的类型以 及当时的国际格局(鲍德温, 2001)。Hegre(2000)认 为, 相对于发展中国家之间的经济往来而言, 发达 国家之间的经济相互依赖可能更能够促进和平。 也有研究表明, 只有民主国家之间的相互依赖能够 促进和平; 民主与非民主国家、以及非民主国家之 间的相互依赖会引发更加频繁的冲突 (Gelpi et al, 2003)。还有研究表明, 在贸易集团或国际组织内 部国家之间的相互依赖才能促进和平, 成员国与非 成员国、或非成员国之间的经济联系则会导致更频 繁的冲突(Mansfield et al, 2000)。

近年来, 从经济相互依赖的视角对区域冲突的 研究逐渐由国家层面转向 “复合尺度下多主体的社 会一空间中的经济往来”(Yeung, 2005), 研究领域从 单一的贸易转向其他经济领域, 研究尺度从国家间 的经济往来转向其他非政府层面, 如跨国公司所带 来的影响(Newman et al, 2011; 罗伯特-基欧汉等 2012), 并运用多种定量模型进行分析 (Grieco,
1988)。学者们通过引人经济变量, 如 GDP、价格弹 性(Gasiorowski, 1986; Polachek et al, 1992)、经济增 长率(Oneal et al, 1996)等, 再结合其他诸如地理邻 近性(Oneal et al, 1997)、政权类型(Barbieri, 1996, 1997)等非经济变量, 利用回归分析 (Gasiorowski, 1986; Mansfield, 1994)、概率统计(Domke, 1988)、逻 辑回归分析(Barbieri, 1996, 2002; Oneal et al, 1996, 1997)等多种分析模型,通过相关性来评价国家之 间维持和平或产生冲突的机制(表 1)。但由于对变 量的篎选和定义的不同以及数据样本的差异(广艳 湘, 2010), 实证研究结果对于经济相互依赖能否引 起冲突没有最终定论(余万里, 2003), 也未能从空间 角度得出国家间经济相互依赖对地缘政治格局变 化的影响规律。

\subsection{2 地缘政治空间扩展}

随着全球化的纵深发展以及各国经济联系的 日益密切,国家利益的地理界限已经突破,地缘政 治空间的扩张更多地通过经济途径来实现。利用

表 1 国家间经济相互依赖与冲突/和平定量研究

Tab.1 Quantitative research about economic interdependence and conflicts between nations

\begin{tabular}{|c|c|c|}
\hline 模型类型 & 文献 & 贸易往来对和平/冲突的作用 \\
\hline \multirow[t]{6}{*}{ 预期收益模型 } & Polachek, 1980 & 促进和平 \\
\hline & Copeland, 1996 & 既能促进和平又能引发冲突 \\
\hline & Polachek, 1997 & 促进和平 \\
\hline & Polachek et al, 1997 & 促进和平 \\
\hline & Polachek et al, 1999 & 促进和平 \\
\hline & Cai et al, 2013 & 促进和平 \\
\hline \multirow[t]{4}{*}{ 合作博亦模型 } & Grieco, 1990 & 引发冲突 \\
\hline & Snidal, 1991a, 1991b & 促进和平 \\
\hline & Powell, 1991 & 促进和平 \\
\hline & Gowa, 1994 & 无影响 \\
\hline \multirow[t]{4}{*}{ 非合作博峦模型 } & Skaperdas et al, 1996 & 两国博弯时促进和平, 多国博栾时引发冲突 \\
\hline & Morrow, 1997 & 促进和平 \\
\hline & Dorussen, 1997 & 既能促进和平又能引发冲突, 视情况而定 \\
\hline & Dorussen, 1999 & 取决于参与国家的数量 \\
\hline \multirow[t]{6}{*}{ 实证主义 } & Gasiorowski, 1986 & 既能促进和平又能引发冲突 \\
\hline & Domke, 1988 & 既能促进和平又能引发冲突 \\
\hline & $\begin{array}{l}\text { Polachek et al, 1992; } \\
\text { Polachek, 1992, } 1997\end{array}$ & 引发冲突 \\
\hline & Onealet al, 1996, 1997 & 引发冲突 \\
\hline & Barbieri, 1995, 1996, 1997 & 引发冲突 \\
\hline & Mansfield, 1994 & 贸易往来促进和平, 全方位经济开放引发冲突 \\
\hline 社会网络分析法 & Maoz, 2009 & 促进和平 \\
\hline 合成模型 & Newman et al, 2011 & 视市场范围与管理范围匹配程度和博弯情况而定 \\
\hline
\end{tabular}


经济途径拓展利益空间是运用经济联系(如投资和 贸易等), 通过增强经济上的依赖性来谋求在全球 经济体系和区域经济体系层次上的优势地位。

从世界范围来看, 运用国家间经济相互依赖这 一经济途径拓展国家地缘政治空间主要有两大趋 势。(1)以周边地区为基础, 逐步向 “大周边” 以及世 界范围内外溢和扩张(陈迎春, 2013); 2)各国加大了 对 “外新月形地区” 的争夺。区位和自然环境在决 定世界权力结构和国家利用经济途径拓展地缘空 间的过程中发挥着重要作用(约翰斯顿, 2004), 也是 国家利用经济途径拓展地缘空间的重要决定因素, 当前世界地缘政治空间的争夺已经从麦金德提出 的“心脏地带”转向“外新月形地带”,如非洲地区。 美、日、英、法、澳等国通过对外投资、联合开采矿产 资源的方式展开对这一地区的争夺, 中国也在近年 来逐年增加对非洲的投资额度。将外商直接投资 转化为自身的竞争力, 充分利用市场和优化资源配 置, 增加非洲地区对外部的依赖性, 从而达到拓展 地缘政治空间的目的(张娟等, 2012)。

\section{4 研究展望}

国家和国家集团之间是由贸易和投资等经济
活动联系在一起的,在经济交往的过程中往往会产 生经济上的相互依赖,随着相互依赖的加深以及国 家和国家集团对经济交往活动规模、范围以及市场 规范等方面诉求的增强,经济联盟和经济组织应运 而生; 反过来, 经济联盟和经济组织能促进国家之 间的经济往来,进而加深国家之间的相互依赖。在 此博峦和互动的过程中,伴随着地缘政治格局在空 间上的改变(图 1)。

在经济途径如何影响地缘政治格局的研究中, 学者们面临的最大挑战在于如何从理论的分析向 定量评价转变, 并选择有效的数据和具体的国家进 行实证研究。在现有的研究成果中,多数集中在对 经济途径影响机制的定性描述, 只有少数研究将经 济相互依赖的影响效用进行了定量化; 同时在国家 的选择上倾向于美国、日本、欧盟等发达国家和国 家集团，而对弱国、小国如何利用经济相互依赖以 及加人经济组织和联盟来增强自身的话语权研究 较少。中国学者对于中国如何利用与其他国家之 间的经济相互依赖关系, 以及通过加人经济组织和 经济联盟等经济途径来提高对地缘政治格局的影 响力研究也很不够。

当前, 中国已成为世界第二大经济体和世界第 一货物贸易大国。中国经济的迅速崛起正在改变

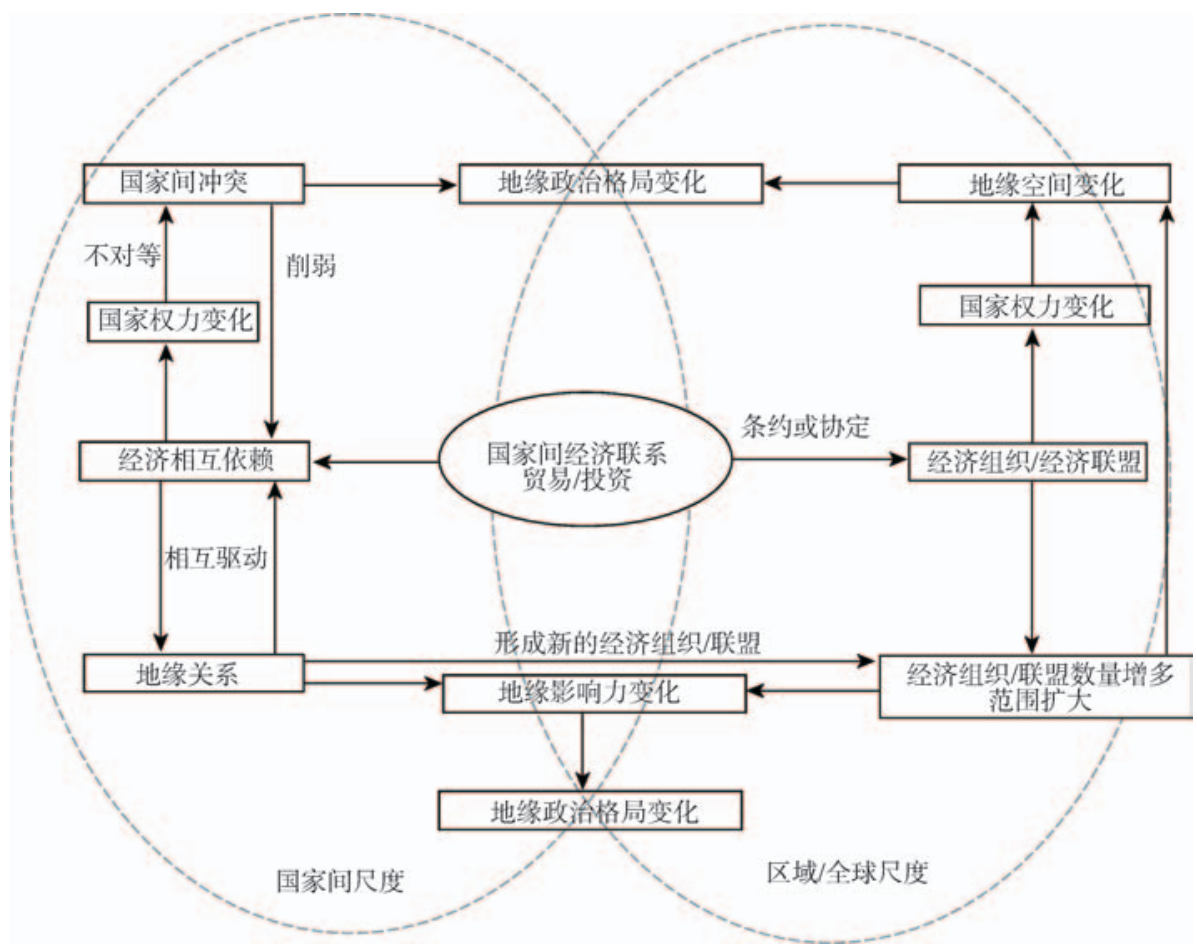

图 1 经济途径对地缘政治格局影响机制示意图

Fig.1 How economic approaches influence geopolitical structure 
周边乃至世界的地缘政治格局, 在全球战略东移 (Mohan, 2013)的背景下, 由中国崛起带来的世界权 力中心转移和国际格局变动, 对中国地缘战略研究 提出了新的要求,也为地缘政治学的发展带来新的 历史机遇(杜德斌等, 2015)。从中国经济发展与地 缘环境的实际出发, 未来需加强以下几个方面的 研究:

第一, 如何将经济相互依赖转化成为有效的地 缘影响力, 拓展中国的地缘政治空间。虽然近年来 有学者根据国家之间的经济相互依赖关系定量测 算了中国(Wang et al, 2015)、日本(胡志丁等, 2014)、 美国(王淑芳等, 2015)等大国在中国周边热点地区 的地缘影响力, 但如何发挥这种存在于国家之间经 济相互依赖中的地缘优势来增强中国对周边乃至 世界的影响力尚未进行很好地阐述, 而且研究范围 只集中在几个大国, 并没有发展成为具有普适性的 理论体系和研究方法。因此, 如何将经济优势转化 成为政治领域中的影响力, 并将这种影响力作为解 决实际问题的助力应作为未来研究的方向之一。

第二, 如何利用国际经济组织和经济联盟拓展 中国地缘战略空间, 满足中国和平崛起的需要。中 国近年来积极倡导区域合作, 如积极构建中国一东 盟“10+1”、“10+3”等平台,加强与东盟国家的合作; 通过金砖国家联盟加强与俄罗斯、巴西、印度、南非 的战略合作; 通过签订中韩、中澳自贸协定等经济 协议加强与亚太地区主要国家的联系; 特别是通过 倡导成立亚洲基础设施投资银行和金砖国家开发 银行, 推动现有机构适应国际格局的演变。目前对 这些举措的研究多从国际关系的角度进行, 地理学 者也应该与时俱进, 将关注点聚焦全球地缘政治和 地缘经济格局的变化, 发挥地理学在空间及区域研 究中的优势, 加强对中国所倡导的区域合作以及经 济组织的空间走向和参与国选择等方面的研究, 为 提高中国在国际社会中的战略地位提供决策支持。

第三, “一带一路”空间走向及沿线国家的相关 研究。2013 年, 习近平主席相继提出建设“丝绸之 路经济带” 和 “ 21 世纪海上丝绸之路” 的战略构想 后, 中国在陆海两个方向上建立起一系列的经济合 作机制。包括 “中俄蒙经济走廊”、“新亚欧大陆 桥”、“中国一中亚经济走廊”、“中印孟缅经济走 廊”、“中巴经济走廊”等由东到西、由北到南贯通亚 洲大陆的陆上经济通道, 以及从东向西贯通“太平 洋一印度洋”的海上经济通道。“一带一路”战略在
安全方面、尤其是发展空间上的重大拓展,其空间 布局和走向打开了陆海两个方向通向欧洲、非洲和 中亚、西亚、南亚、东南亚的经济大门,有助于更好 地实现中国东西两翼战略的再平衡, 拓展中国发展 的地缘战略空间。在未来的研究中, 应充分发挥地 理学综合性、区域性及动态性的优势, 加强“一带一 路”区域内各国资源、环境、经济发展空间布局、空 间差异及空间规划等方面的研究, 推动“一带一路” 沿线国家区域经济一体化进程。

第四,如何通过不同尺度的经济途径改善中国 周边地缘环境。中国与周边国家在经济上均存在 不同程度上的相互依赖,既有势均力敌也有差距悬 殊。中国应结合与周边国家在发展上的历史脉络, 根据与不同国家的经济相互依赖关系状况, 以及近 周边和大周边范围内经济组织和经济联盟参与国 的状况,制定针对不同国家和区域的地缘战略, 通 过多尺度经济途径, 改善提升中国周边的地缘 环境。

第五,对主要国家和地区的实证研究。以中国 大周边国家为例, 采用定量模拟方法, 探求国家地 缘影响力的演变因素以及驱动机制, 从地缘政治与 地缘经济方面提供提供理论支撑和研究实证。在 研究过程中,还应注意数据的真实性和准确性。例 如, 有些数据并非由官方网站提供, 就可能影响研 究的准确性以及研究结果的可靠程度; 同时, 部分 研究中所选择的数据不能够很好地反映所研究的 内容, 如仅用一国的贸易数据就不能全面反映该国 与其他国家的经济联系。因此, 在未来研究中, 应 提高数据选择的准确度和精确度, 力求全面、准确 地反映研究内容, 并得出真实可靠的研究结论。

第六, 还应加强国际经济组织和联盟中国家主 权让渡的研究, 为中国争取利益最大化。在经济全 球化浪潮中, 为了推进贸易自由化和经济一体化, 相互让渡部分主权已经成为各国常态, 但让渡的主 权应限制在经济和贸易领域, 同时要有利于本国经 济发展且让渡必须对等,否则将损害国家尊严和民 族利益。作为一个发展中国家, 中国经济的抗风险 能力还比较弱。国际范围内发生了多次的金融风 暴和经济危机表明,高度的开放市场往往伴随着更 高的危机风险。中国在融人世界经济体系的进程 中, 应取长补短, 有所为有所不为。通过自身实力 的不断提高, 改善地缘政治环境, 使世界范围内的 地缘政治格局朝向有利于中国方向发展。 


\section{参考文献(References)}

鲍德温. 2001. 新现实主义和新自由主义[M]. 肖欢容, 译. 杭 州: 浙江人民出版社. [Baldwin D A. 2001. Neorealism and Neoliberalism[M]. Xiao H R, Trans.. Hangzhou, China: Zhejiang People's Publishing House.]

陈迎春. 2013. 论海外利益与中国的地缘经济空间 [J]. 发展 研究, (3): 19-24. [Chen Y C. 2013. Lun haiwai liyi yu Zhongguo de diyuan jingji kongjian[J]. Development Research, (3): 19-24.]

杜德斌, 段德忠, 刘承良, 等. 2015. 1990 年以来中国地理学 之地缘政治学研究进展 [J]. 地理研究, 34(2): 199-212. [Du D B, Duan D Z, Liu C L, et al. 2015. Progress of geopolitics of Chinese geography since 1990[J]. Geographical Research, 34(2): 199-212.]

胡志丁, 刘玉立, 李灿松, 等. 2014. 权力、地缘环境与地缘位 势评价: 以中日钓鱼岛之争为例 $[\mathrm{J}]$. 热带地理, 34(1): 50-57. [Hu Z D, Liu Y L, Li C S, et al. 2014. Power, geosetting and evaluation method of geo-potential: A case study of the dispute over China and Japan on the Diaoyu islands[J]. Tropical Geography, 34(1): 50-57.]

胡志丁, 陆大道. 2015. 基于批判地缘政治学视角解读经典 地缘政治理论 [J]. 地理学报, 70(6): 851-863. [Hu Z D, Lu D D. 2015. The re-interpretation of the classical geopolitical theories from a critical geopolitical perspective [J]. Acta Geographica Sinica, 70(6): 851-863.]

华尔兹. 2003. 国际政治理论 [M]. 信强, 译. 上海: 上海人民 出版社. [Walts K. 2003. Theory of international politics [M]. Xin Q, Trans.. Shanghai, China: Shanghai People's Publishing House.]

金灿荣. 2008. 国际地缘政治格局变化及其对中国的影响 [J]. 现代国际关系, (5): 12-14. [Jin C R. 2008. Changes in international geopolitics and their impacts on China[J]. Contemporary International Relations, (5): 12-14.]

孔小惠. 2000. 地缘政治的涵义、主要理论及其影响国家安 全战略的途径分析 [J]. 世界地理研究, 19(2): 19-26. [Kong X H. 2000. Analyze on ways of geopolitics affecting a state's security strategy[J]. World Regional Studies, 19(2): 19-26.]

广艳湘. 2007. 和平还是冲突: 经济相互依赖的政治后果 $[\mathrm{J}]$. 国际论坛, 9(3): 44-48. [Kuang Y X. 2007. Peace or conflict: The political consequences of economic interdependence[J]. International Forum, 9(3): 44-48.]

广艳湘. 2010. 经济相互依赖、退出成本与国家间冲突升级: 基于动态博峦模型的理论分析 [J]. 世界经济与政治, (4): 123-138. [Kuang Y X. 2010. Economic interdependence, exit cost and conflict escalation: A theoretical analysis based on dynamic game model[J]. World Economics and Politics, (4): 123-138.]

李正, 陈才, 熊理然. 2014. 欧美地缘经济理论发展脉络及其 内涵特征探析 [J]. 世界地理研究, 23(1): 10-18. [Li Z, Chen C, Xiong L R. 2014. An analysis on the theory origin and development vein of geo- economics abroad[J]. World Regional Studies, 23(1): 10-18.]

林利民. 2012. 未来 5 10 年亚太地缘政治变局与中国 [J]. 现 代国际关系, (4): 8-15, 62. [Lin L M. 2012. Weilai 5 10 nian Yatai diyuan zhengzhi bianju yu Zhongguo[J]. Contemporary International Relations, (4): 8-15, 62.]

刘雪莲, 徐立恒. 2011. 当代地缘政治学研究的新视域与新 动向 [J]. 山东社会科学, (1): 134-137. [Liu X L, Xu L H. 2011. The new sight and trend of contemporary geopolitics[J]. Shandong Social Sciences, (1): 134-137.]

陆大道, 杜德斌. 2013. 关于加强地缘政治地缘经济研究的 思考 [J]. 地理学报, 68(6): 723-727. [Lu D D, Du D B. 2013. Some thoughts on the strengthening of geopolitical and geo-economic studies[J]. Acta Geographica Sinica, 68 (6): 723-727.]

吕涁. 2015. “一带一路”与中国的地缘政治战略 $[\mathrm{J}]$. 科学・经 济・社会, 33(1): 50-54. [Lv B. 2015. "The Silk Road Economic Belt and the Marine Silk Road" and the geopolitical strategy of China $[\mathrm{J}]$. Science $\cdot$ Economy $\cdot$ Society, 33 (1): 50-54.]

毛汉英. 2014. 中国周边地缘政治与地缘经济格局和对策 [J]. 地理科学进展, 33(3): 289-302. [Mao H Y. 2014. Geopolitical and geo-economic situation around and China's strategies[J]. Progress in Geography, 33(3): 289302.]

罗伯特 ·基欧汉, 约瑟夫 ·奈. 2002. 权力与相互依赖 [M]. 门 洪华, 译. 北京: 北京大学出版社. [Keohane R O, Nye J S. 2002. Power and interdependence[M]. Men $\mathrm{H} \mathrm{H}$, Trans.. Beijing, China: Peking University Press.]

王淑芳, 葛岳静, 刘玉立. 2015. 中美在南亚地缘影响力的时 空演变及机制[J]. 地理学报, 70(6): 864-878. [Wang S F, Ge Y J, Liu Y L. 2015. The spatio-temporal evolution and driving mechanism of geopolitical influence of China and the US in South Asia[J]. Acta Geographica Sinica, 70(6): 864-878.]

王在邦. 2008. 全球化进程与地缘政治格局的演变 [J]. 现代 国际关系，(5): 1- 2. [Wang Z B. 2008. Quanqiuhua jincheng yu diyuan zhengzhi geju de yanbian[J]. Contemporary International Relations, (5): 1-2.]

余万里. 2003. 相互依赖研究评述 [J]. 欧洲研究, (4): 51-61.

[Yu W L. 2003. A study of interdependence[J]. Chinese Journal of European Studies, (4): 51-61.]

约翰斯顿 R J. 2004. 人文地理学词典[M]. 柴彦威, 等, 译. 北 
京: 商务印书馆. [Johnston R J. 2004. The dictionary of human geography[M]. Chai Y W, et al, trans.. Beijing, China: The Commercial Press.]

张根海. 2012. “上海合作组织” 区域合作机制: 一个新的视 角 [J]. 学术论坛, 35(9): 53- 57. [Zhang G H. 2012. "Shanghai hezuo zuzhi" quyu hezuo jizhi: Yige xinde shijiao[J]. Academic Forum, 35(9): 53-57.]

张娟, 刘钻石. 2012. 中国对非洲直接投资与资源寻求战略 [J]. 世界经济研究, (3): 75-80. [Zhang J, Liu Z S. 2012. China's outward FDI in Africa and resource-seeking strategy[J]. World Economy Study, (3): 75-80.]

张胜军. 2004. 全球化与国际组织的新角色 [J]. 国际论坛, 6 (3): 14-19. [Zhang S J. 2004. Globalization and the new role of international organizations[J]. International Forum, 6(3): 14-19.]

周启元. 1991. 论国际经济组织的形成、性质和作用 [J]. 吉林 大学社会科学学报, (1): 41-47. [Zhou Q Y. 1991. Lun guoji jingji zuzhi de xingcheng, xingzhi he zuoyong[J]. Jilin University Journal Social Sciences Edition, (1): 4147.]

Barbieri K. 1995. Economic interdependence and militarized interstate conflict, 1870-1985[D]. Binghamton, NY: Department of Political Science, Binghamton University.

Barbieri K. 1996. Economic interdependence: A path to peace or a source of interstate conflict[J]. Journal of Peace Research, 33(1): 29-49.

Barbieri K. 1997. Risky Business: The impact of trade linkages on interstate conflict, 1870-1985[M]//Schneider G, Weitsman P A. Enforcing cooperation: "Risky" states and intergovernmental management of conflict. London, UK: Macmillan: 202-231.

Barbieri K. 2002. The liberal illusion: Does trade promote peace[M]. Ann Arbor, MI: University of Michigan Press.

Barbieri K, Levy J S. 1999. Sleeping with the enemy: The impact of war on trade[J]. Journal of Peace Research, 36(4): 463-479.

Barbieri K, Schneider G. 1999. Globalization and peace: Assessing new directions in the study of trade and conflict [J]. Journal of Peace Research, 36(4): 387-404.

Cai J, Ma Y, An L, et al. 2013. Conflict or cooperation: Political relationship and trade development between US and China[J]. International Center for Business Research, 2: 25-37.

Capannelli G, Lee J W, Petri P A. 2010. Economic interdependence in Asia: Developing indicators for regional integration and cooperation[J]. The Singapore Economic Review, 55(1): 125-161.
Cooper R N. 1968. The economics of interdependence[J]. The International Executive, 10(4): 3-5.

Copeland D C. 1996. Economic interdependence and war: A theory of trade expectations[J]. International Security, 20 (4): 5-41.

Dent C M. 1999. The European Union and East Asia: An economic relationship[M]. London \& New York: Routledge.

Dodds K. 2001. Political geography III: Critical geopolitics after ten years[J]. Progress in Human Geography, 25(3): 469-484.

Domke W K. 1988. War and the changing global system[M]. New Haven, CT: Yale University Press.

Dorussen H. 1997. Trade coalitions and the balance of power [N]. Paper presented at the ECPR Joint Sessions of Workshops. Bern, Switzerland.

Dorussen H. 1999. Balance of power revisited: A multi-Actor models of trade and conflict[J]. Journal of Peace Research, 36(4): 443-462.

Evans M. 2011. Power and paradox: Asian geopolitics and Sino- American relations in the 21 st century[J]. Orbis, 55 (1): 85-113.

Ganesan N. 2000. ASEAN's relations with major external powers[J]. Contemporary Southeast Asia, 22(2): 258-278.

Gasiorowski M J. 1986. Economic interdependence and international conflict: Some cross-national evidence[J]. International Studies Quarterly, 30(1): 23-38.

Gelpi C, Grieco J M. 2003. Economic interdependence, the democratic state, and the liberal peace $[\mathrm{M}] / /$ Mansfield $\mathrm{E}$ D, Pollins B M. Economic interdependence and international conflict: New perspectives on an enduring debate. Ann Arbor, MI: University of Michigan Press: 44-59.

Gowa J. 1994. Allies, adversaries, and international trade[M]. Princeton, NJ: Princeton University Press.

Grieco J M. 1988. Anarchy and the limits of cooperation: A realist critique of the newest liberal institutionalism[J]. International Organization, 42(3): 485-507.

Grieco J M. 1990. Cooperation among nations: Europe, America, and Non-tariff barriers to trade[M]. Ithace, NY \& London: Cornell University Press.

He K. 2008. Institutional balancing and international relations theory: Economic interdependence and balance of power strategies in Southeast Asia[J]. European Journal of International Relations, 14(3): 489-518.

Hegre H. 2000. Development and the liberal peace: What does it take to be a trading state[J]. Journal of Peace Research, 37(1): 5-30.

Hirschman A O. 1980. National power and the structure of for- 
eign trade[M]. Berkeley, CA: University of California Press.

Keohane R O. 2005. After hegemony: Cooperation and discord in the world political economy[M]. Princeton, NJ: Princeton University Press.

Keohane R O, Nye J S. 1987. Power and interdependence revisited[J]. International Organization, 41(4): 725-753.

Krause L B, Nye J S. 1975. Reflections on the economics and politics of international economic organizations[J]. International Organization, 29(1): 323-342.

Mansfield E D. 1994. Power, trade, and war[M]. Princeton, NJ: Princeton University Press

Mansfield E D, Pevehouse J C. 2000. Trade blocs, trade flows, and international conflict[J]. International Organization, 54(4): 775-808.

Maoz Z. 2009. The effects of strategic and economic interdependence on international conflict across levels of analysis[J]. American Journal of Political Science, 53(1): 223240.

McGowan P J, Rood R M. 1975. Alliance behavior in balance of power systems: Applying a Poisson model to nineteenth-century Europe[J]. The American Political Science Review, 69(3): 859-870.

Mohan C R. 2013. Emerging geopolitical trends and security in the association of Southeast Asian nations, the People's Republic of China, and India (ACI) region[R]. Asian Development Bank Institute.

Morrow J D. 1997. When do "relative gains" impede trade[J]. Journal of Conflict Resolution, 41(1): 12-37.

Murphy A B. 2013. Trapped in the logic of the modern state system? European integration in the wake of the financial crisis[J]. Geopolitics, 18(3): 705-723.

Newman A L, Posner E. 2011. International interdependence and regulatory power: Authority, mobility, and markets [J]. European Journal of International Relations, 17(4): 589610.

Oneal J R, Oneal F H, Maoz Z, et al. 1996. The liberal peace: Interdependence, democracy, and international conflict, 1950-85[J]. Journal of Peace Research, 33(1): 11-28.

Oneal J R, Russet B M. 1997. The classical liberals were right: Democracy, interdependence, and conflict, 1950-1985[J]. International Studies Quarterly, 41(2): 267-294.

Oneal J R, Russett B M. 1999. The Kantian peace: The pacific benefits of democracy, interdependence, and international organizations, 1885-1992[J]. World Politics, 52(1): 1-37.

Oneal J R, Russett B M, Berbaum M L. 2003. Causes of peace: Democracy, interdependence, and international or- ganizations, 1885-1992[J]. International Studies Quarterly, 47(3): 371-393.

Papayoanou P A. 1997. Economic interdependence and the balance of power[J]. International Studies Quarterly, 41(1): 113-140.

Polachek S W. 1980. Conflict and trade[J]. Journal of Conflict Resolution, 24(1): 55-78.

Polachek S W. 1992. Conflict and trade: An economics approach to political international interactions[M]//Isard W, Anderton $\mathrm{C} \mathrm{H}$. Economics of arms reduction and the peace process[M]. Amsterdam, Holland: North-Holland.

Polachek S W. 1997. Why do democracies cooperate more and fight less: The relationship between international trade and cooperation[J]. Review of International Economics, 5 (3): 295-309.

Polachek S W, McDonald J. 1992. Strategic trade and the incentive for cooperation[M]//Chatterji M, Forcey L. Disarmament, economic conversion, and management of peace. New York: Praeger: 273-284.

Polachek S W, Robst J, Chang Y C. 1997. 'Geographic proximity and interdependence: The relationship between distance, trade and international interactions'[R]. Binghamton University \& Chinese Cultural University.

Polachek S W, Robst J, Chang Y C. 1999. Iiberalism and interdependence: Extending the trade-conflict model[J]. Journal of Peace Research, 36(4): 405-422.

Powell R. 1991. Absolute and relative gains in international relations theory[J]. American Political Science Review, 85 (4): 1303-1320.

Skaperdas S, Garfinkel M. 1996. Competitive trade with conflict[M]. New York: Cambridge University Press.

Snidal D. 1991a. International cooperation among relative gains maximizers[J]. International Studies Quarterly, 35 (4): 387-402.

Snidal D. 1991b. Relative gains and the pattern of international cooperation[J]. American Political Science Review, 85 (3): 701-726.

Sparke M. 2007. Geopolitical fears, geoeconomic hopes, and the responsibilities of geography[J]. Annals of the Association of American Geographers, 97(2): 338-349.

Stein A A. 2003. Trade and conflict: Uncertainty, strategic signaling, and interstate disputes[M]//Mansfield E D, Pollins B M. Economic interdependence and international conflict: New perspectives on an enduring debate. Ann Arbor, MI: University of Michigan Press: 111-126.

Thomes A. 2013. The borders of solidarity: Trade unions, social entitlements and regional integration[J]. Geopolitics, 
18(1): 157-177.

Wagner R H. 1988. Economic interdependence, bargaining power, and political influence[J]. International Organization, 42(3): 461-483.

Walt S M. 1985. Alliance formation and the balance of world power[J]. International Security, 9(4): 3-43.

Walt S M. 1987. Origins of alliances[M]. Ithaca, NY: Cornell
University Press.

Wang S F, Cao Y, Ge Y J. 2015. Spatio-temporal changes and their reasons to the geopolitical influence of China and the US in South Asia[J]. Sustainability, 7(1): 1064-1080.

Yeung H W C. 2005. Rethinking relational economic geography[J]. Transactions of the Institute of British Geographers, 30(1): 37-51.

\title{
Progress of research on impacts of economic approaches on geopolitical structure and spatial expression
}

\author{
CAO Yuan ${ }^{1,2}$, GE Yuejing ${ }^{1,3}$, WANG Shufang ${ }^{1}$, HU Zhiding ${ }^{3}$ \\ (1. School of Geography, Beijing Normal University, Beijing 100875, China; 2. School of Geography, University \\ of Wisconsin-Madison, Madison 53706, USA; 3. Collaborative Innovation Center for Geopolitical Setting of \\ Southwest China and Borderland Development, Yunnan Normal University, Kunming 650500, China)
}

\begin{abstract}
With the rise of China's economic and political power, many large countries in the world shift their strategic focus on Asia and try to influence China's regional political economic environment through various economic organizations and unions, which result in a complicated environment for China's development. China responds to the situation through the creation of the "Belt and Road Initiative", Asian Infrastructure Investment Bank, and BRICS Development Bank. In this article, we discuss the mechanism of influence of international economic organizations, economic unions, and national economic interdependence on geopolitical structure and their spatial expression at the global, regional, and national levels. The results show that: asymmetric economic interdependence can influence national power and power distribution in world geopolitical structure, with the spatial expression of regional conflicts and change of spatial scope of influence of countries. International economic organizations and unions can influence global and regional geopolitical structure by rebalancing power, with a spatial expression of growth of influence, mosaic distribution, and spatial expansion. Within China there has been little research on how China can enhance its geopolitical influence and improve the geopolitical environment by economic approaches. In the future, research should focus on how to transform economic interdependence into effective geopolitical influence; how to expand geopolitical space by using international economic organizations and unions; the "Belt and Road" strategy, especially with regard to the spatial trends and country situations in areas that the initiative involves; and research on multi-scale economic approaches and application of quantitative models to provide theoretical support and empirical evidence for the development of China's geopolitical strategy.
\end{abstract}

Key words: economic approaches; geopolitical structure; economic interdependence; international economic organizations; economic unions 